\title{
MARTINHO LUTERO (1483-1546) E TOMÁS MÜNTZER (1489-1525): A justificação teológica da autoridade secular e da revolução política
}

Martin N. Dreher ${ }^{*}$

SÍNTESE - A Reforma em território alemão possui duas figuras, por vezes próximas entre si, por vezes muito distantes: Lutero e Tomás Müntzer. À medida que foi se envolvendo na vida de seus fiéis, Müntzer foi tomando caminhos próprios, discordando de Lutero que este tomava a "Palavra, em sua realidade objetiva, como constitutiva da Igreja, e afirmando que os verdadeiros fiéis são os que possuem a experiência subjetiva do "Espírito". Também contra Lutero, que defende a resistência à autoridade, mas em questões seculares aceita a tirania, Müntzer, que vê a fé fortemente inserida no social, defende a revolução armada contra os príncipes. Müntzer não nega a graça, mas esta possui papel secundário em seu pensamento, enquanto, para Lutero, ela se coloca no centro de suas preocupações teológicas. PALAVRAS-CHAVE - Reforma. Palavra. Graça. Experiência subjetiva. Resistência. Revolução.
ABSTRACT - The Reform in german territory has two figures, sometimes very close to each other, and sometimes very distant: Luther and Thomas Müntzer. As he got envolved in the lives of his followers, Müntzer began taking his own paths, disaccording of Luther that took the "Word" in its objective reality, as constitutive of the Church, and affirming that the true followers are the ones who own the subjective experience of the "Spirit". Also against Luther, that stands for the resistance against authority, but in secular matters accepts tyranny, Müntzer, that sees tyranny deeply inserted in the social, stands for the armed revolution against the princes. Müntzer does not deny grace, but it has a secondary role in his thought, as, for Luther, it is placed in the center of his theological worries.

KEY WORDS - Reform. Word. Grace. Subjective experience. Resistance. Revolution.

\section{I}

No contexto da história da Reforma, Thomas Müntzer é uma das personagens mais controvertidas. Lutero escreveu "uma carta aos príncipes da Saxônia a respeito do espírito da reboldosa", ${ }^{1}$ enquanto que os batistas de Zurique, mesmo

Universidade do Vale do Rio dos Sinos / São Leopoldo, RS.

"Ein Brief an die Fürsten zu Sachsen von dem aufrührischen Geist" de julho de 1524, WA 15, 210s.

\begin{tabular}{|l|l|l|l|l|l|}
\hline VERITAS & Porto Alegre & v. 51 & n. 3 & Setembro 2006 & p. 145-168 \\
\hline
\end{tabular}


tecendo críticas, designaram-no de "veraz e fiel mensageiro do Evangelho". ${ }^{2}$ Essas duas maneiras de ver Müntzer perpassam a história. Ernst Bloch pôde afirmar: "Münzer é, antes de mais nada, história em seu sentido fértil; ele e o que é seu e tudo o que é passado e que valha a pena ser anotado, está aí para nos comprometer, para nos entusiasmar a fortalecer sempre mais o que continuamente se dirige a nós". ${ }^{3}$ Paul Althaus, em contraposição, vê "o lúgubre, negro fervor das idéias teocrático-taboritas" que ligavam Müntzer à "exasperação dos camponeses" confrontados com a "pureza ética" do posicionamento de Lutero na Guerra dos Camponeses. ${ }^{4}$ - Müntzer atrai alguns e recebe o desprezo de outros. Qual a causa desses posicionamentos?

Hans-Jürgen Goertz reconheceu, a meu ver corretamente, que os historiadores que procuram esclarecer e justificar os posicionamentos de Lutero na Guerra dos Camponeses têm pouca simpatia para com os posicionamentos de Müntzer. ${ }^{5}$ Por isso, o "reformador sem Igreja" ficou entregue aos historiadores marxistas. ${ }^{7}$ E, com isso, lamentavelmente, entrou na dança da briga entre cristãos e marxistas. Goertz formula essa situação magistralmente: "Müntzer caiu no moinho das discussões entre cristianismo e marxismo; e isso teve conseqüências funestas para a interpretação de seus escritos. Normalmente a teologia cristã não se sente atraída pela revolução; e o marxismo pouco consegue fazer com a teologia. Müntzer, no entanto, era duas coisas: revolucionário e teólogo". Há sempre grandes dificuldades em se conseguir, na pesquisa, coadunar a argumentação teológica de Müntzer com sua agitação revolucionária. Alguns não entendem Müntzer, por não quererem entender sua revolução, outros não o entendem, porque não querem compreender sua teologia. Müntzer é um homem que procurou fundamentar a revolução teologicamente.

Quem era esse homem, qual sua teologia? Como entender seu principal contendor, Martinho Lutero?

\section{II}

Procuro apresentar Müntzer, colocando-o ao lado de seu grande opositor: Lutero. É impossível falarmos de um, sem falarmos do outro. A tragédia de um é a tragédia do outro ${ }^{9}$. Ambos se preocuparam com Deus e sua Palavra, com seu Espí-

2 Cf. Hans-Jürgen Goertz, Der Mystiker mit dem Hammer, in: Abraham Friesen e Hans-Jürgen Goertz, Thomas Müntzer (WdF CDXCI). Darmstadt: Wissenschaftliche Buchgesellschaft, 1978, p. 404.

3 Ernst Bloch, Thomas Müntzer als Theologe der Revolution, Frankfurt am Main 1962, p. 9.

Paul Althaus, Luthers Haltung im Bauernkrieg, Darmstadt: Wissenschaftliche Buchgesellschaft, 1971, p. 31 e 60

Op. cit., p. 405s

Cf. Eric Gritsch, Reformer without a Church. Thomas Müntzer, Philadelphia, 1967.

Cf. Abraham Friesen. Die ältere und die marxistische Müntzerdeutung, in: Abraham Friesen e Hans-Jürgen Goertz, Thomas Müntzer (WdF CDXCI), Darmstadt: Wissenschaftliche Buchgesellschaft, 1978, p. 447-480, esp. 461s.

8 Op. cit., p. 406.

9 A mais completa biografia sobre Müntzer nos é oferecida por Walter Elliger, Thomas Müntzer. Leben und Werk. Göttingen: Vandenhoeck \& Ruprecht, 1975. 
rito, com sua revelação e com a vinda do Reino de Deus. Na compreensão que ambos tinham do Evangelho é que nós os podemos compreender, entendendo assim também suas divergências.

Müntzer nasceu, por volta de 1490, em Stolberg, na região do Harz. Sua família fazia parte da burguesia, financeiramente bem-situada. ${ }^{10}$ Pouco sabemos a respeito de seus estudos em Leipzig (1506) e em Frankfurt an der Oder (1512). Pouco sabemos também a respeito de sua atividade, após a interrupção de seus estudos, iniciados em Leipzig. Após alguns semestres de estudo, Müntzer abandonou os estudos em Leipzig para assumir a função de colaborador do ministério eclesiástico e funções de mestre-escola. ${ }^{11}$ Aqui talvez tenha descoberto os vícios da vida eclesiástica de então. Em 1513 ou 1514, foi ordenado sacerdote. ${ }^{12}$ Em 1516, concluiu seus estudos em Frankfurt an der Oder. Ainda nesse ano assumiu as funções de prepósito no convento feminino de Frose/Anhalt, onde em 1517 e 1518 entrou em contato com a discussão que se acendia em torno do professor da Universidade de Wittenberg, Martinho Lutero. Até 1520 Müntzer trocou por diversas vezes o local de suas atividades. Nesse período, de 1517 a 1520, tornou-se adepto da causa luterana. Por indicação de Lutero, Müntzer se tornou, em 1520, pregador do evangelho na cidade de Zwickau. Não há motivos que nos possam fazer duvidar da sinceridade de Müntzer ao abraçar a causa luterana.

Müntzer passou. assim como Lutero, por profundas dúvidas. Mas há diferenças nessas dúvidas. Enquanto Lutero quis entender Deus, cheio de sentimentos de culpa, medo e pavor de Deus, Müntzer enfrentou um sentimento quase niilista da distância de Deus, desesperando por não possuir a Deus e o seu poder. Perguntava pela existência de Deus e martirizava-se com a questão se a doutrina de Cristo era realmente procedente de Deus. ${ }^{13}$ Esta situação de Müntzer se reflete em palavras de uma carta sua:

Aí o homem pensa que não tem fé nenhuma. Sim, segundo lhe parece, não encontra fé alguma. Ele sente ou encontra um anseio muito pequeno à procura da verdadeira fé, que é tão fraco que mal e dificilmente consegue vislumbrar em si. Finalmente, ele o tem que arrancar de dentro de si, dizendo: Ai de mim, mísero homem, o que me move em meu coração? Minha consciência consome toda minha seiva e força e tudo o que sou. Ah, que hei de fazer? Fiquei desorientado, sem qualquer consolo de me encontrar com Deus e a criatura. Deus me castiga com minha consciência, com descrença, desespero e com sua blasfêmia. Exteriormente sou atacado com doença, pobreza, misé-

${ }_{10}$ Walter Elliger, op. cit., p. 9s. As estilisticamente belas formulações de Bloch não passam de fruto da fantasia: "Es war trübe um ihn von vorn an. Fast verlassen wuchs der junge düstere Mensch auf. Müntzer wurde als einziger Sohn kleiner Leute um 1490 in Stolberg geboren. Sein Vater hat er frühe verloren, seine Mutter wurde übel behandelt, man suchte sie, als angeblich mittellos aus der Stadt zu weisen. Der Vater soll, ein Opfer gräflicher Willkür, am Galgen geendet haben. So erfuhr schon der Knabe alle Bitternisse der Schande und des Unrechts", Bloch, op. cit., p. 16. A mãe de Müntzer faleceu em fins de 1520 ou princípios de 1521. A morte do pai ocorre, quando Müntzer já se encontra em Mühlhausen, portanto após a morte da esposa. Cf. Elliger, op. cit., p. 12 e 15.

Walter Elliger, op. cit., p. 26.

2 Walter Elliger, op. cit., p. 39.

13 Cf. quanto a todo o problema Hayo Gerdes, Der Weg des Glaubens bei Müntzer und Luther, in: Abraham Friesen e Hanz. Jürgen Goertz, Thomas Müntzer (WdF CDXCI). Darmstadt: Wissenschaftliche Buchgesellschaft, 1978, p. 16-30. 
ria e todo o tipo de necessidade, da parte de gente má, etc... E isso me acossa interiormente muito mais que o exterior. Ah, como gostaria de crer direito, se tudo dependesse disso, se ao menos eu soubesse qual é o caminho correto. Sim, eu correria até o fim do mundo. ${ }^{14}$

À semelhança de Lutero, Müntzer ocupou-se com os místicos alemães. Desde 1516, Lutero animava seus alunos e adeptos a que lessem as obras de Tauler e de outros místicos alemães. Desde 1519, Müntzer começou a ler João Tauler e Henrique Seuse. A leitura dessas obras marcou-o profundamente. Nas obras desses místicos encontrou a afirmação, que o tornou extremamente feliz, de que Deus primeiro lança a todos os seus amigos na noite do desespero - assim como ele, Müntzer, o havia experimentado - antes de permitir que o seu sol brilhe sobre eles. Nesses místicos, Müntzer encontrou, ainda, a afirmação - que ainda mais felicidade lhe trouxe - de que o eterno Deus, sem meios exteriores, se revela palpavelmente aos seus no mais profundo da alma. No sentido mais profundo da palavra, o homem pode sentir Deus e ter certeza absoluta dele. A única coisa indispensável, a ser feita, da parte do homem, é a "desbrutalização" (Entgröbung), i.é, o abandono de tudo o que não é Deus. Müntzer tomou dos místicos aquilo que lhe faltava em suas lutas interiores: Deus pode revelar-se sem meios externos, mas ele tão-somente se revela àquele que anteriormente experimentou a "noite". Ele experimentara a "noite", mas ainda não experimentara Deus. ${ }^{15}$ Nessa procura por uma experiência com Deus foi-lhe importante o encontro com o tecelão Nicolau Storch. Storch liderava, em Zwickau, um grupo de uma espécie de cristianismo leigo, encontradiço na Idade Média tardia. Esses leigos tinham bons conhecimentos bíblicos e diziam ter feito experiências com o Espírito Santo. Falavam que também os demais cristãos deveriam estar em condições de prestar contas de sua fé pessoal e de serem possuidores do Espírito. ${ }^{16}$ Nesse grupo de Zwickau encontramos influências da linha taborita dos hussitas. Pretendiam eles erigir o Reino de Deus, eliminando todos os não-crentes. Müntzer adotou não só o cristianismo de Storch e de seu grupo, mas também a idéia da concretização terrestre do Reino de Deus, difundida pelos taboritas. ${ }^{17}$ Aqui, ao que tudo indica, Müntzer se sentiu chamado a fundar a Nova Igreja Apostólica.

Para melhor compreender a visão que Müntzer tem dessa Nova Igreja Apostólica, é bom compararmos seu conceito eclesiológico com o de Lutero. Lutero cunhou, de forma decisiva, o princípio "democrático" do sacerdócio universal de todos os crentes. Com esse princípio, teve a alavanca para fazer vacilar a Igreja institucional e hierárquica de seu tempo. Igreja era para ele a livre reunião de todos os crentes em Cristo, a comunhão invisível dos que estão ligados pela fé e pelo amor. Caso só existissem cristãos, não mais haveria a necessidade de organismos políticos humanos; nenhum reino, Estado, lei ou organização civil. A Igreja, segundo Lutero, não surge, nem é mantida a partir dos indivíduos, mas a partir

\footnotetext{
Carta citada em Gerdes, op. cit., p. 23s.

Walter Elliger, op. cit., p. 66-73.

Cf. Reinhard Schwarz, Die apokalyptische Theologie Thomas Müntzer und der Taboriten, Tübingen: Mohr, 1977, p. 15s.

Cf. quanto a isso o todo da obra de Schwarz.
} 
de algo objetivo que está fora deles e sobre eles: a Palavra. Para que essa Palavra seja corretamente ensinada e pregada, surge novamente uma instituição exterior, visível, uma Igreja exterior, visível, no seio da qual existe a verdadeira Igreja, a Igreja invisível. Ao lado do culto de pregação da Igreja visível, existe apenas uma única forma de culto: o serviço e o trabalho nas ordenações da vida normal: na profissão e no Estado, no matrimônio e na família. Essas ordenações da vida normal são praticamente incluídas no conceito de Igreja que encontramos em Lutero. Com isso, o conceito luterano de Igreja abarca todos os setores da vida humana em comunhão. ${ }^{18}$

Carl Hinrichs ${ }^{19}$ mostrou, claramente, que em Müntzer não encontramos tal diferenciação no conceito de Igreja. Igreja é, para ele, primordialmente, uma categoria sociológica para a vida humana em comunhão. Constitutiva para essa Igreja não é a realidade objetiva da "Palavra", que cria e forma o cristão, mas a experiência subjetiva do "Espírito", que, "antes e sobre toda a tradição da escritura, dormita no indivíduo e tem que ser despertada" ${ }^{20}$ Aqui temos a concepção de uma religião imanente que existe no coração humano, desde a criação do gênero humano, antes do surgimento de uma Escritura que contém a Palavra. O Espírito dessa religião se manifestou nos Patriarcas e nos Profetas, em Cristo, nos Apóstolos e pode manifestar-se em todo o ser humano. Todos os seres humanos têm em si a possibilidade de possuir o verdadeiro Espírito; essa possibilidade torna todos os homens iguais, pois perpassa todas as classes e diferenças nacionais. A ação do Espírito elimina todas as diferenças, não só diante de Deus, mas de fato, pois o Espírito cria uma comunhão dos por ele "eleitos" e, através dessa comunhão, uma nova realidade social. Historicamente, Müntzer vê esta nova realidade social concretizada na comunhão sem classes e sem propriedade privada da comunidade primitiva de Jerusalém. Igreja é, para Müntzer, uma comunhão, sem classes e sem a existência de propriedade privada, dos "eleitos", através da posse do Espírito. Em outras palavras: Igreja é um ideal social, onde inexistem Estado, classes, propriedade privada. Quem exige esse tipo de Igreja, o único verdadeiro, é o Espírito que age independentemente da Palavra; ele é inerente a todos os homens, é um princípio uniformizador de toda a vida, exigindo a uniformização de toda a vida social, segundo a vontade de Deus que pode ser conhecida por todos os seres humanos.

Se compreendemos essa caracterização de Igreja, que encontramos em Müntzer, podemos ver por que ele não pôde aceitar a conceituação luterana que fala de Igreja visível e invisível, e que admite ao lado da visão de uma Igreja invisível a existência autônoma de Estado e sociedade. "'Igreja' é para ele a união dos eleitos, através da experiência direta do Espírito e da Vontade de Deus, e o estado

${ }^{18}$ Cf. quanto à eclesiologia de Lutero, Joachim Fischer, O conceito "Igreja" de Lutero segundo seus escritos "Dos Concílios e da Igreja" e "Contra Hans Worst", em: Estudos Teológicos 6. 1966(4), p. 161-175; Mário L. Rehfeldt, O desenvolvimento do conceito de Igreja de Lutero até 1521, Porto Alegre: Concórdia, 1966. Hans Joachim Iwand, Luthers Theologie (Nachgelassene Werke, vol. 5), München: Kaiser, 1974, p. 226-308.

19 Carl Hinrichs, Luther und Müntzer. Ihre Auseinandersetzung über Obrigkeit und Widerstandsrecht. Berlin, 1952, p. 44s.

20. Carl Hinrichs, op cit., p. 45. 
final perfeito da humanidade, sem instituição estatal, sem propriedade, realizado aqui na terra e que conclui ou encerra a história que até aqui ocorreu" ${ }^{21}$ Igreja é Reino de Deus implantado de maneira definitiva.

Se compreendemos esse conceito eclesiológico de Müntzer, podemos entender por que Lutero não o pôde acompanhar. Aqui havia, no dizer de Lutero, um outro Espírito.

Em Zwickau surgiu, pois, um outro Müntzer, diferente de Lutero, adversário de Lutero. Em Zwickau, Müntzer não conseguiu edificar sua Nova Igreja Apostólica. Disputas ${ }^{22}$ levaram-no a se dirigir a Praga. Em 1523, foi chamado a se tornar pastor de Allstedt. As diferenças teológicas em relação a Lutero continuaram a se evidenciar. Mesmo assim podemos constatar que, em muitos sentidos, Müntzer contínua a assumir posicionamentos luteranos. Introduziu o culto divino em língua alemã. ${ }^{23}$ Lutero só chegou a isso em 1526. Em Allstedt, Müntzer casou com uma ex-freira, Ottilie von Gersen, com quem teve um filho. ${ }^{24}$ Lutero faria o mesmo, em 1525, ao casar com Catarina von Bora. Vemos aqui atitudes paralelas entre o discípulo e o mestre.

Como pregador, em Allstedt, Müntzer atraía multidões. Tanto assim que vinham grupos de Estados vizinhos para ouvir sua pregação. Isso levou a que príncipes católicos se voltassem contra ele, proibindo seus súditos de viajarem até Allstedt. Müntzer não deixou a questão passar em brancas nuvens. Dirigiu palavras vigorosas contra os príncipes. Lutero também o fez. Em Müntzer, porém. encontramos algo mais: ameaçou os príncipes católicos com oposição total, afirmando não mais reconhecê-los como autoridade! Aqui há diferença fundamental em relação a Lutero. ${ }^{25}$

Müntzer se sabe incumbido por Deus como seu mensageiro. Logo no início de um escrito seu de $1524,{ }^{26}$ em que apresentou sua doutrina, Müntzer faz referências a Malaquías 3 (na versão de Almeida 4.5-6): "Eis que eu vos enviarei o profeta Elias, antes que venha o grande e terrível dia do Senhor; ele converterá o coração dos pais aos filhos, e o coração dos filhos a seus pais" ${ }^{27}$ Ele se sabe enviado para chamar a cristandade à conversão, para que ela voltasse a ser o que fora nos tempos dos apóstolos e para que fosse eliminada toda a "fé poesia".

Müntzer não era apenas teórico da fé, mas também um prático da fé. A partir daí, pode-se entender um outro fato, acontecido em Allstedt. Naquela cidade existia uma capela com uma imagem de Maria, da qual se dizia ter propriedades milagrosas. Certa noite, após uma série de ameaças, a capela estava em chamas. O fato foi denunciado às autoridades, e Müntzer denunciado como responsável. Não se conseguiu provar a autoria do incêndio, mas as inflamadas pregações de

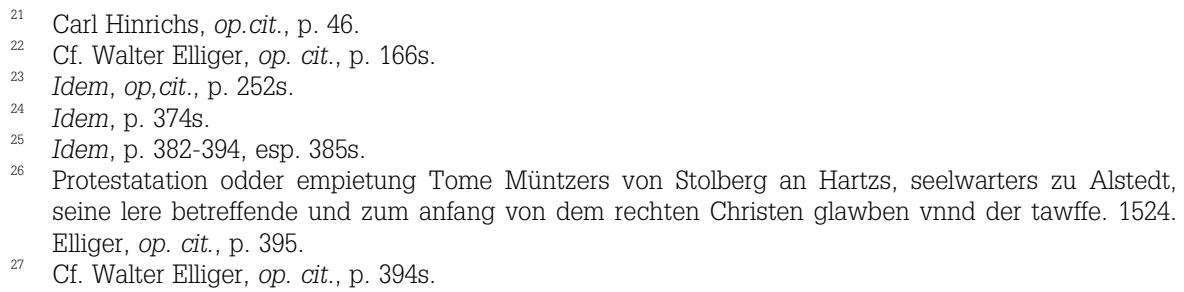


Müntzer contra a capela não deixaram dúvidas quanto à autoria intelectual do atentado. ${ }^{28}$ Foi aberto um inquérito para procurar os responsáveis. Tal procedimento provocou a ira de Müntzer e mostrou, uma vez mais, a visão que ele tinha de si mesmo: homem chamado a fazer uma reforma radical. Seria o profeta anunciado por Malaquias 3. Ele não conseguia compreender que uma autoridade dita cristã atacasse as pessoas que destruíram a morada de Satanás, a capela de Maria. A autoridade foi instituída, segundo Paulo, e a ela dada a espada para proteger os piedosos (no caso, aqueles que destruíram a capela) e para castigar os ímpios (aqueles que veneravam a imagem da capela). A autoridade deve obediência ao que foi escrito em Êxodo 23: Não defenderás o ímpio. Monges e freiras são ímpios. Como pode a autoridade defender monges e freiras que defendem o culto a Maria? Essa convicção, expressa em carta de junho de $1524,{ }^{29}$ evidencia que a autoridade só é reconhecida como instituída por Deus, caso estiver disposta a se colocar ao lado de Müntzer e de seu Evangelho.

No decorrer do inquérito, Frederico, o Sábio, príncipe-eleitor da Saxônia, enviou seu irmão, João, o Constante, e o filho deste a Allstedt para ouvir pregação de Müntzer. O texto dessa pregação foi Daniel 2, o sonho de Nabucodonosor. ${ }^{30}$ Talvez se possa perguntar: Por que Daniel 2 e não Romanos 13? Basta lembrar o conteúdo de Daniel 2, para compreender por que Müntzer escolheu esse texto ao ter que pregar diante de seu príncipe. Esse texto é, para ele, resumo de sua teologia. Relembremos Daniel 2: O rei babilônico Nabucodonosor teve um sonho que o encheu de inquietação e de incerteza. Por isso, convocou seus magos, encantadores, feiticeiros e caldeus e, para prová-los e ver se tinham condições de lhe dar interpretação autêntica, proveniente de uma esfera supra-humana, exigiu deles que lhe dissessem o conteúdo e a interpretação de seu sonho. Caso não o conseguissem, seriam executados como mentirosos e charlatães. Os magos asseguraram que nenhum mortal estava em condições de fazer tal coisa. Somente os deuses poderiam fazê-lo, mas estes não moravam com os homens. O rei, então, ordenou a matança de todos. Essa ordem afetaria também a Daniel, homem entendido em visões e sonhos, bem como a seus companheiros. Daniel, porém, pediu e conseguiu, do rei, uma moratória; orou a Deus, pedindo revelação. A soberania do Deus judeu mostrou-se, então, ao dar a Daniel a conhecer, em uma visão à noite, o sonho de Nabucodonosor e a sua interpretação. Daniel apareceu diante do rei e narrou-lhe o sonho: O rei viu uma grande estátua, cuja cabeça era de ouro, o peito e os braços de prata, o ventre e os quadris de bronze, as pernas de ferro, os pés parcialmente de ferro e parcialmente de barro. Sem auxílio de mão humana desprende-se de uma montanha uma pedra, atinge a estátua em seus pés de ferro e barro, fazendo com que desmorone, e seus pedaços são espalhados pelo vento como palha. A pedra que destruíra a estátua transforma-se em grande montanha e enche toda a Terra. A interpretação é: haverá quatro períodos na história, nos quais tudo vai piorando e ficando mais difícil. O autor de Daniel pensa nos reinos

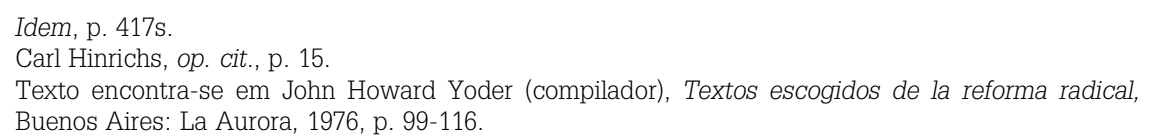


babilônio, medo, persa e grego. O fim deste último reino é "um reino dividido", o reino dos Diádocos, que não pode permanecer unido. Nessa última época, encerra-se a seqüência de reinos universais. Deus suscita um reino que destrói todos os demais e permanece eternamente. Ao ouvir a interpretação de Daniel, Nabucodonosor louvou o Deus de Daniel como Deus dos deuses e Senhor dos reis, pôs Daniel sobre todos os sábios e deu-lhe o governo da província de Babilônia. A pedido de Daniel, seus amigos foram colocados no governo da província e ele permaneceu na corte do rei.

Nesse texto, Müntzer encontrou sua visão de história e também sua própria situação. De um lado, encontrava-se o governante, Frederico, o Sábio, homem sem muita segurança, cujos conselheiros (Lutero e asseclas) não conseguiam mostrar-lhe o caminho a ser seguido. Não o conseguiam, por não crer em inspiração direta do Espírito, oferecendo tão-somente interpretações não inspiradas da Escritura. De outro lado, encontrava-se Daniel-Müntzer que ainda tinha contato direto com a revelação direta e que, por isso, estava em condições de dar interpretação correta da situação histórica que se atravessava.

A pregação sobre o texto de Daniel 2 está subdividida em quatro partes.

1. Na primeira parte, Müntzer desenvolve a concepção de que a história da Igreja é a história da progressiva deteriorização de uma situação inicial ideal. Cristo e seus apóstolos e, antes deles, os profetas, deram início a uma cristandade pura, mas seus sucessores foram maus servidores da Igreja que não tiveram 0 fervor necessário para levar a cabo o que Cristo iniciara. A Igreja iniciada logo estava em ruínas. ${ }^{31}$ Esta concepção é introduzida por Müntzer no esquema da história universal que encontra em Daniel 2. Cristo é para ele o monte da visão que Daniel tem a respeito da história. Desse monte desprende-se, sem o concurso de mão humana, uma pedra, destinada a pôr fim à história, ao destruir o último reino. ${ }^{32}$ Essa pedra é o Espírito de Cristo que rola através do último período da história. A montanha, Jesus Cristo, nasceu numa época em que "reinava a pior das escravidões..., na época de Otávio, quando todo o mundo estava em movimento e era recenseado". Naquela época, "um espírito débil (Augusto), miserável saco de lixo (Drecksack), quis apoderar-se do mundo inteiro, mesmo que este não lhe servisse mais que para esplendor e vaidade. Sim, chegou a imaginar que somente ele era grande". ${ }^{33}$ Em contraposição: "Ó, que pequena era, então, a pedra angular, Jesus Cristo, aos olhos dos homens. Foi empurrado para um estábulo como um dejeto humano" ${ }^{34} \mathrm{O}$ Espírito por ele enviado, a pedra que se soltou do monte, na época não pôde cumprir sua missão de exterminar a última monarquia. "A pedra ainda não encheu toda a Terra", ${ }^{35}$ pois o fervor de seus servos esmoreceu. Em conseqüência, a pedra foi detida pelos príncipes. Com isso, foi iniciado o quinto período da história, portador do estigma da decadência, denominado por

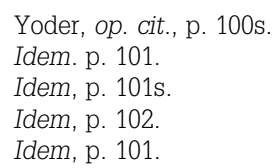


Müntzer de "tempo do mundo dividido". ${ }^{36}$ Esse "tempo do mundo dividido" é a época da dílaceração da cristandade em dois poderes: Igreja e Estado, e da ligação da Igreja com o poder secular. Desde então, vem-se representando a peça teatral da paixão (crítica ao sacrifício da missa) e o "Cristo crucificado real" foi transformado "em ídolo assaz enganoso" ${ }^{37}$ Os pobres camponeses foram iludidos com respeito ao verdadeiro significado do Espírito de Cristo, pois "em seu lugar foi colocada uma bela, delicada e áurea divindade, ante a qual os pobres camponeses ficam se babando". "A besta do ventre... e os porcos" pisotearam "a pedra preciosa" de tal maneira que ela se transformou em "refugo". Com essas expressões, Müntzer quer evidenciar que, com a ligação da Igreja com o Estado, a Igreja, originalmente pura, se viu degradada à função de sustentáculo do Estado e do sistema fundiário vigente. Com seu mágico culto cerimonial, com seu culto às imagens, ela ocultou aos pobres e oprimidos o verdadeiro caráter revolucionário do Espírito de Cristo. Diante dessa constatação, Müntzer apela aos príncipes: "Por isso, amados irmãos, devemos ressurgir desta imundície e ser verdadeiros discípulos de Deus, ensinados por Deus... E assim necessitaremos de uma grande e poderosa força que nos será dada de cima, para castigar e debilitar esta indizível maldade". Deve-se usar "mão poderosa contra os inimigos de Deus".

2. Na segunda parte, Müntzer continua a desenvolver sua reflexão a respeito do desprezo e da adulteração da "pedra" e demonstra que esta abominação não é apenas uma característica da velha Igreja, do catolicismo romano, mas também de seus novos adversários, os astutos escribas semelhantes a Lutero. ${ }^{39}$ Para que se possa reconhecer essa realidade, tem que se ter certeza da revelação diária de Deus, revelação que ele faz no tempo presente. Condição para tanto é o temor de Deus. ${ }^{40}$ É a experiência da severidade e do rigor de Deus e da exigência incondicional de sua lei, o "espanto" da alma humana, quanto a seu estado de enredamento no mundo, que a torna receptível à revelação de sua vontade. Ela somente é pura, quando elimina todo o temor diante de homens e criaturas que querem impedir a realização da vontade divina ${ }^{41}$. Por isso, os príncipes são conclamados a "nesses perigosos dias empregar o máximo zelo... para resistir a este insidioso mal".

Por que os dias atuais são perigosos, por que os dias são maus? Porque "a pobre gente ignorante" está sendo novamente enganada "por escribas ímpios" que "ensinam e dizem que Deus já não revela seus segredos divinos a seus queridos amigos, por meio de visões verdadeiras ou de sua palavra audível... e fazem objeto de burla os homens que se ocupam com a revelação". Cheios de deboche perguntam: "Ouve! Deus andou te dizendo alguma coisa ultimamente? ou: Interrogaste ultimamente a boca de Deus e celebraste conselho com ele? Tens o Espí-

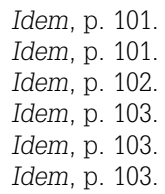


rito de Cristo?" ${ }^{\prime 2} \mathrm{O}$ perigo dos dias atuais reside no fato de que a fé de Lutero, baseada na letra morta, sem experiência do Espírito, é vendida como o que há de mais novo, enquanto que a fé realmente nova de Müntzer, sua experiência da ação direta do Espírito, com todas as suas conseqüências revolucionárias é desprezada e impedida de se concretizar. Lutero e seus colaboradores são comparados com os sábios de Nabucodonosor que não souberam dar explicações ao rei, por não crerem em Deus e em suas revelações diretas: "Não tinham fé em Deus; eram ímpios, hipócritas e aduladores que diziam o que seus senhores queriam ouvir, como os escribas de nossa época que gostam de comer delicados manjares na corte". ${ }^{43}$

3. Na terceira parte, Müntzer desenvolve, em rápidos traços, sua concepção do ouvir da palavra interna no "abismo da alma", sem o que nenhum homem pode dizer algo profundo a respeito de Deus, "ainda que haja devorado cem mil Bíblias". ${ }^{4}$ A verdadeira palavra não se encontra nem na letra da Escritura, nem na "luz natural" da razão, mas no coração humano, e o homem somente se apercebe dela, quando Deus lhe envia "o impulso" ao coração. Este "impulso" é cruz, necessidade, aflição. Através desse "impulso", Deus mata "os apetites carnais", "afasta todas as diversões" e o homem está "resolutamente disposto para a verdade". ${ }^{45}$

4. Na quarta parte, temos o centro da pregação. Nela Müntzer reúne sua teologia do Espírito com sua visão da história, chegando a uma aplicação políticorevolucionáría. Aqui temos a síntese de seu pensamento.

Inicialmente Müntzer complementa sua idéia de que nenhum homem com "apetites carnais" pode entender a palavra de Deus que quer se manifestar em seu íntimo." "Porque os espinhos e cardos, isto é, os prazeres deste mundo... afogam todo o efeito da palavra que Deus diz à alma. Por isso, ainda que Deus diga à alma sua sagrada palavra, o homem não a ouvirá, se não se houver exercitado, porque não se volta para dentro de si mesmo, nem vê dentro de si e nos abismos de sua alma. O homem não quer crucificar sua vida com seus vícios e desejos, como ensina Paulo... Por isso, a lavoura da palavra de Deus está cheia de cardos, de espinhos e de grandes arbustos, todos os quais têm que ser arrancados para esta obra divina, a fim de que a pessoa não seja considerada negligente ou preguiçosa" ${ }^{47}$ Os vícios e desejos deste mundo são riqueza, glória, honra, poder; estes têm que ser arrancados. É o chamado à revolução. "A fertilidade do campo e, por último, a abundante produção dependem dessa revolução. Quando forem arrancados, eliminados, riqueza, glória, honra, poder, somente então a pessoa cobra consciência de que ele é morada de Deus e do Espírito Santo por toda sua vida, mais ainda, que realmente só foi criado para inquirir os testemunhos de Deus em

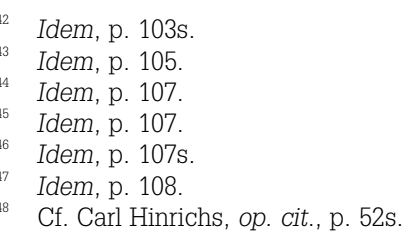


sua própria vida". ${ }^{49} \mathrm{O}$ alvo da revolução é levar a pessoa a sua verdadeira finalidade. Esta é, para Müntzer, uma vida com e em Deus. A mudança das condições políticas e sociais vigentes criará a possibilidade para a redenção da humanidade do mal. Havendo mudança das condições externas de vida, ocorrerá também a mudança interna. Müntzer pergunta: "Pois, se a cristandade não tivesse que ser apostólica, ... para que se prega? ${ }^{\prime 50}$

Müntzer faz uma série de considerações a respeito de como se reconhecem visões e sonhos autênticos, ${ }^{51}$ para acentuar que, nos sonhos e visões autênticos, está novamente agindo o Espírito profético que revela as intenções de Deus para com a história. Pois a comprovação do Espírito profético é a característica clara e evidente de que a transformação do mundo ocorre logo, especialmente quando ele se manifesta entre os desprezados e pequeninos, na massa do povo. Básica para essa afirmação de Müntzer é a passagem de Joel 2.27-32: "Sabereis que estou no meio de Israel, e que sou o Senhor vosso Deus e não há outro; e o meu povo jamais será envergonhado. E acontecerá que derramarei o meu Espírito sobre toda a carne; vossos filhos e vossas filhas profetizarão, vossos velhos sonharão, e vossos jovens terão visões; até sobre os servos e sobre as servas derramarei o meu Espírito naqueles dias. Mostrarei prodígios no céu e na terra; sangue, fogo, e colunas de fumo. O sol se converterá em trevas e a lua em sangue, antes que venha o grande e terrível dia do Senhor". Este texto traz para Müntzer a visão da revolução social. Ela provém do Espírito livre de qualquer tradição que se derrama "sobre toda a carne", sobre todos. Müntzer sabe que este texto está citado em Atos 2, mas não foi no cristianismo primitivo que ocorreu o fim da história. Os sucessores dos apóstolos foram preguiçosos e, por isso, o Espírito não foi derramado "sobre toda a carne". Agora, nos dias de Müntzer, chegou o momento de que fala Joel. "É verdade, diz Müntzer, e sei que é certo que o Espírito de Deus está revelando a muitos homens retos, eleitos, que é mui necessária uma profunda, inevitável reforma vindoura e que esta deve ser levada a cabo, ainda que cada qual se defenda como quiser" ${ }^{52}$ A veracidade dessa constatação de Müntzer é comprovada por Daníel 2. Ele atesta que o momento esperado é chegado: "Este texto de Daniel é claro como o sol, e o processo do final do quinto reino do mundo está em pleno avanço".

Müntzer passa a descrever o desenrolar dos diversos períodos. ${ }^{53} \mathrm{O}$ primeiro reino, representado pela cabeça dourada, foi o da Babíionia. O segundo, com peito e braços de prata, é o reino dos medos e persas. O terceiro foi o reino dos gregos que se tornou conhecido "por sua inteligência (simbolizada pelo bronze)". O quarto foi o império romano "que foi conquistado com a espada e foi um reino de coerção" (imperialismo e absolutismo). Müntzer vê nos pés da estátua um quinto reino: "Mas o quinto é este que temos ante os olhos, que também é de ferro e também queria aplicar a coerção. Mas está remendado com barro (Kot)". Interpreto: O Estado com o qual Müntzer se vê confrontado é um Estado de coerção, tal qual o

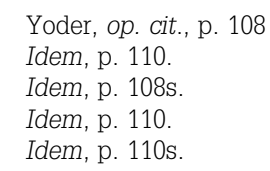


romano, mas está remendado com elementos pretensamente crístãos: remendado com as vãs pretensões da hipocrisia que rasteja e pulula por sobre a Terra". A mistura de secular e espiritual que se encontra neste reino é descrita por Müntzer: "Agora se vê como as enguias e víboras, amontoadas, se unem entre si. Os monges e todos os maus sacerdotes são víboras... e os senhores temporais e governantes são enguias". Aqui o Senhor vai fazer limpeza "com uma vara de ferro!".

Feita essa exposição, Müntzer parte para a aplicação: "Por isso, amadíssimos e estimados príncipes, recebei vosso juízo diretamente da boca de Deus e não vos deixeis desorientar por vossos hipócritas clérigos (referência a Lutero), nem sejais detidos por uma falsa consideração e indulgência. Porque a pedra arrancada, não com mão, da montanha cresceu. Os pobres leigos e camponeses vêem-na com muito maior clareza que vós". ${ }^{54}$ Aqui está a evidência: o povo recebeu o Espírito, os governantes estão impotentes. Nessa constatação está um estímulo e ameaça para os príncipes saxões: "Sim, louvado seja Deus, (a pedra) tornou-se tão grande que, se outros senhores ou vizinhos vos quiserem perseguir por causa do Evangelho, seriam combatidos por seu próprio povo. Sei-o com certeza. Sim, a pedra é grande. O mundo estúpido assustou-se ante ela. Ela atacou-o, quando ainda era pequena. Que faremos agora que se tornou tão grande e poderosa e que bateu com força incontível contra a estátua?" ${ }^{\prime 55}$ Com uma autoconfiança incrível, Müntzer convoca os príncipes saxões a assumirem a causa da pedra que está destruindo a estátua: "Por isso, estimados príncipes da Saxônia, firmai-vos com decisão sobre a pedra angular... e buscai a verdadeira firmeza proporcionada pela vontade divina... . Porque Deus está tão próximo de vós que não o podeis crer. Por que haveríeis de vos horrorizar ante o fantasma do homem?" ${ }^{\prime 56}$ Müntzer está convicto de que, se os príncipes reconhecerem o verdadeiro estado em que se encontra a cristandade, ficarão tão furiosos como o rei Jeú que exterminou as dinastias de Israel e Judá. Essa fúria deverá aliar-se à ira do povo. Para que isso ocorra, tem que surgir um novo Daniel que interprete a revelação que os príncipes receberam, "e ele deve marchar à frente" ${ }^{57}$ Que devem os príncipes fazer? "Não outra coisa que apartar os perversos que se opõem ao Evangelho e eliminá-los, se não quereis ser realmente filhos do demônio, ao invés de servidores de Deus". A autoridade somente é ministro de Deus (Romanos 13!), quando elimina os maus. Esta é a ordem de Cristo (Lucas 19.27): "Quanto a esses meus inimigos que não quiseram que eu reinasse sobre eles, trazei-os aqui e executai-os na minha presença". Müntzer é incisivo: "Se vós quereis ser bons governantes, deveis iniciar o governo desde as raizes e como Cristo o ordenou. Afugentai seus inimigos de entre os eleitos! Pois vós sois o meio para esse fim. Amados, não vos deis escusas ocas, como a de que o poder de Deus deve f azê-lo, sem a intervenção de vossa espada!"58 Essas colocações são claramente contra a exegese de Lutero! A este Lutero não se deve dar ouvidos. O que vale é: "O homem ímpio não tem direito de viver, onde estorva os

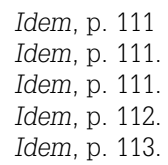


justos". Caso os príncipes derem ouvidos aos escribas luteranos e se negarem a usar sua espada em favor dos piedosos "eleitos", contra os "maus", mudando as condições de vida, como o exige Romanos 13, "a espada lhes será tirada". ${ }^{59}$

Müntzer faz propostas concretas para a ação dos príncipes. Inicialmente, eles devem oferecer a paz aos "inimigos" do Evangelho, lembrá-los da verdadeira palavra de Deus e procurar convencê-los ${ }^{60}$ Se não se opuserem à revelação de Deus, devem ser poupados, "mas, se se opõem a ela, que sejam degolados sem clemência, assim como Ezequias, Josias, Ciro, Daniel e Elias exterminaram os profetas de Baal. Não há outra maneira de a Igreja cristã voltar a suas origens" . ${ }^{11}$ Aqui vemos o que Müntzer quer: a volta da humanidade a um estágio social que já houve no passado, se bem que passageiramente, "o comunismo do amor" da cristandade primitiva. Para que esse alvo seja alcançado, devem ser eliminados todos aqueles que se opõem à vontade de Deus. "Tem que se arrancar a cizânia do horto de Deus, quando chegar a época da colheita. Então o formoso trigo vermelho adquirirá boas raízes e crescerá devidamente. Mas os anjos, que para isso afiam suas foices, são os sérios servidores de Deus que executam a ira da sabedoria divina". ${ }^{62}$ Os cheios de Espírito provocam o fim da história.

Nessa pregação de Müntzer se evidencia que ele quer a revolução e não a evolução pregada por Lutero. O fim da velha Igreja não deve ser confiado apenas à "palavra". Finda essa velha Igreja, deve surgir uma nova ordem social. Por isso a lei divina exige que se "matem os governantes ímpios, especialmente os freis e monges que nos infamam o Evangelho como uma heresia" ${ }^{63}$ Para que a verdade vença, os príncipes devem agir assim como Nabucodonosor no final de Daniel 2. Ali Nabucodonosor põe Daniel sobre todos os sábios e dá-lhe o governo da província de Babilônia. Com isso, Müntzer aponta para si próprio: ele liderará a revolução. A pregação encerra com a exclamação: "Se temos a Deus, por que haveríamos de atemorizar-nos ante pessoas relaxadas e incapazes? Sede audazes! O governo será daquele a quem foi dado todo o poder no céu e na terra; que ele, amadíssimos, vos proteja para sempre. Amém" ${ }^{64}$

Também aqui cabe uma comparação entre Lutero e Müntzer, pois é na questão do resistir à autoridade que o conflito entre Lutero e Müntzer se agudiza. Na segunda parte de seu escrito Da Autoridade Secular, ${ }^{65}$ Lutero também fala de resistência à autoridade. Lutero chama à desobediência contra os tiranos, quando eles agem contra o Evangelho, contra a verdade. No entanto, seus direitos de governantes não deveriam ser atingidos. No tocante a questões seculares Lutero, está disposto a obedecer ao pior dos tiranos. A tirania merece castigo, mas é a Deus quem compete impor tal castigo. Müntzer vai além: se a autoridade negar

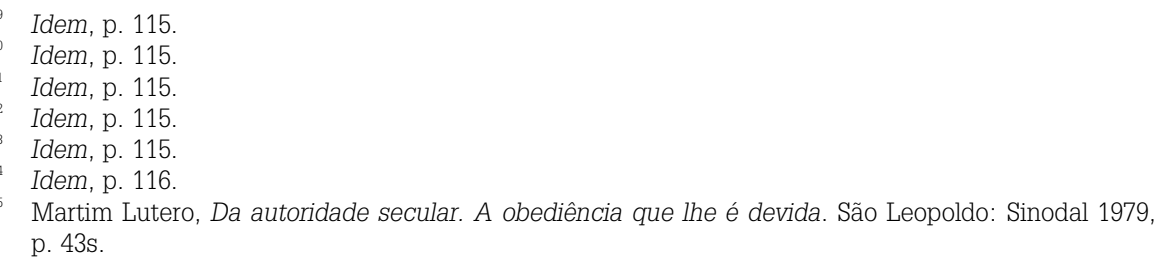


obediência ao Evangelho (de Müntzer!), deve-se negar-lhe toda a obediência e liquidá-la.

A pregação de Müntzer foi publicada. Não se sabe nada da reação dos príncipes a esta pregação. Aparentemente eles não se opuseram à sua publicação. Lutero, porém, veio a público com a publicação de sua Carta aos príncipes da Saxônia a respeito do espírito da reboldosa. Na Carta, Lutero se distancia claramente do cristianismo "espiritual" de Müntzer e de seu espírito revolucionário. A ruptura com Müntzer foi definitiva. Para Müntzer, a ruptura foi um desastre. Seus paroquianos abandonaram-no. Müntzer não conseguiu mais lugar de trabalho. Houve tentativa de se estabelecer em Mülhausen, mas essa tentativa fracassou por causa da polêmica de Lutero e das pressões das autoridades. Do sul veio a negativa dos anabatistas. ${ }^{66}$ Müntzer viajou para o sul da Alemanha, fez publicações. Em fevereiro de 1525 , retornou a Müchausen, onde se tornou pastor. ${ }^{67}$ Durante suas viagens, teve contatos com a incipiente revolta dos camponeses. Retornou convicto de que a hora do novo havia chegado. Sua vida foi determinada pela ação, fazendo convocações para a "luta do Senhor", para a guerra santa. Ele anunciou o juízo de Deus diretamente: "O Deus eternamente vivo nos ordenou destronar-te com a força que nos foi outorgada", ${ }^{8}$ escreve ele a Ernesto de Mansfeld. Exorta os camponeses a não ter piedade: "Adiante, adiante, enquanto o fogo ainda arde. Não permitais que vossa espada perca a cor do sangue". É utópico quanto às possibilidades dos camponeses: "Mesmo que houvesse apenas três de vós que, entregues a Deus, só buscassem seu nome e honra, não temeríeis cem mil" ${ }^{\prime \prime 9}$. Müntzer assina suas cartas com as palavras: "Tomás Müntzer com a espada de Gideão". ${ }^{70}$ Ele é o "servo de Deus", ${ }^{71}$ profeta do juízo, líder dos "eleitos", profeta da guerra, baseando-se na guerra santa e nos guerreiros de Israel: Josué, Elias, Davi e Gideão.

Nos últimos cinco meses de sua vida, Müntzer é um homem amargurado, cheio de ódio. Lutero rompera com ele em 1522, os príncipes da Saxônia não lhe deram ouvidos, outros dele se afastaram. Em sua visão "profética", ele se afastou dos príncipes e se voltou ao povo. O povo camponês estava agitado, estava se organizando. Nesse povo Müntzer viu o sinal dos tempos. Era o sinal para edificar a Igreja espiritual e eliminar os ímpios. Müntzer transformou-se no mais importante agitador e pregador dos camponeses da Turíngia. Para liderar os camponeses, porém, faltava-lhe todo e qualquer conhecimento militar e político. Ele foi de um diletantismo total. Liderou os camponeses na batalha de Frankenhausen. Levaram oito pequenos canhões, mas nada de munição! Ao invés da munição, Müntzer ordenou que os camponeses ostentassem uma espada e uma grande bandeira de seda branca. Sobre a bandeira estava desenhado o arco-íris, sinal da aliança de Deus com os eleitos. Antes da batalha, os príncipes exigiram que Müntzer lhes

Cf. Yoder, op. cit., p. 131-142

Heinrich Bornkamm, Martin Luther in der Mitte seines Lebens. Das Jahrzehnt zwischen dem Wormser und dem Augsburger Reichstag. Aus dem Nachlass herausgegeben von Karin Borkmann, Göttingen:Vandenhoeck \& Ruprecht, 1979, p. 127.

Carta a Ernesto de Mansfeld, em: Yoder, op. cit., p. 127

Carta aos camponeses, em: Yoder, op. cit., p. 125.

Yoder, op. cit., p. 126.

Idem, p. 124. 
fosse entregue. Entregue Müntzer, não haveria batalha; os camponeses poderiam voltar para casa. Müntzer pregou com veemência. Os camponeses não o entregaram. Durante a pregação, apareceu, no céu, o arco-íris. Era o sinal da presença de Deus. Os camponeses começaram a cantar: "Veni, sancte spiritus". Na batalha foram mortos cinco mil camponeses e seis soldados das tropas dos príncipes. Müntzer foi aprisionado, torturado e decapitado em 27 de maio de 1525. Pouco antes de ser decapitado, Müntzer pediu que os príncipes não fossem tão duros com os camponeses e concluiu, dizendo: "leiam libros Regum", leiam os livros dos Reis. A referência aos livros dos Reis é clara: Deus não permite que zombem dele. Ele vai acabar - com a atividade daqueles que não obedecem à sua vontade. Deus não quer um mundo de injustiça e de tirania. Ele quer ser reconhecido como único Senhor. Müntzer admoesta os príncipes com a referência a libros Regum e que não pensem que a derrota dos camponeses, o não de Deus aos camponeses, seria um sim ao governo contrário à vontade de Deus, o governo dos príncipes. ${ }^{72}$

\section{III}

Sabendo-se ensinado por Deus é que Müntzer viu que a estrutura social e de domínio de sua época carecia de mudanças radicais. Ele sabia que a pessoa chamada à fé está inserida e submetida a estruturas da sociedade. Nessa sociedade, vale lucro, ganho, honra, glória. Tudo coisas que somente a Deus competem. Tal sociedade é contra Deus. A "fé poesia" que Müntzer encontra tanto na Igreja romana, quanto em Lutero e seus seguidores legitima a situação de poder e de sociedade existente. Müntzer viu como, em sua sociedade, o Estado ajuda a Igreja e como a Igreja ajuda o Estado, um legitimando as atrocidades do outro. Por isso ele era anticlerical. ${ }^{73}$ Era também contra o Estado existente. Müntzer viu-se diante da necessidade de estourar com a ideologia da cristandade. Igreja e Estado estavam impedindo a verdadeira Reforma. ${ }^{74}$ Para ele, quando ocorre a "conversão" interna, provocada por Deus diretamente no indivíduo, tem que ocorrer também a "conversão" externa. À revolução no indivíduo, que é a mudança provocada por Deus nele, quando fala a ele diretamente pelo Espírito, corresponde a revolução, a mudança na sociedade, na Igreja. A realidade de seu tempo, porém, era a de que a Igreja, ligada ao Estado, estava impedindo a "conversão" do indivíduo. Impedia, com isso, também a mudança, a "conversão" externa. Para Müntzer, conversão interna e conversão externa estão intimamente ligadas. Somente o "eleito" está realmente em condições de mudar o mundo e de chamar outros para mudarem o mundo. Com essa mudança, surge o Reino de Deus. O Reino de Deus no mundo, contudo, vem do Reino que está no coração do ser humano. Com isso, o discipulado é um ato místico-revolucionário. O caráter individual da conversão interna não leva a um apoio das estruturas externas, ou a um indiferentismo em relação a elas, mas à conversão das mesmas.

\footnotetext{
Walter Elliger, op. cit., p. 821s.

Neste ponto ele não está só. É acompanhado pelos anabatistas e pelos humanistas.

Cf. acima a minha exposição a respeito da prédica ante os príncipes.
} 
O esquema de Müntzer é belo: conversão interna leva à conversão externa. Na prática, este esquema não vingou. Houve muitos fatores não-teológicos que levaram seu pensamento ao fracasso. Müntzer, porém, sucumbiu ante o Evangelho que para ele era exigência de Deus e não possibilidade de vida. Não é por acaso que o conceito de graça, revelado no Evangelho, faltou em nossa exposição. Ele não era central para Müntzer. Evangelho é para Müntzer luta contra o pecado no interior e no exterior. A sociedade, o "mundo" são vistos tão-somente como determinados pelo pecado. É certo que existe esse aspecto na realidade da linguagem bíblica, mas não só ele. "Mundo" é para a Bíblia também aquele âmbito que foi dado por Deus ao ser humano e a ele confiado, para nele e em suas estruturas servir a Deus e comprovar a fé individual e socialmente. Müntzer absolutizou o traço negativo da interpretação bíblica do mundo e não levou em conta o fato de que Deus também amou o mundo, aceitando-o em seu filho (João 3,16). ${ }^{75}$ Com isso ele não conseguiu ver a realidade social sob o aspecto da liberdade que Deus dá, liberdade esta que quer levar a uma libertação abrangente do ser humano. Por outro lado, também não conseguiu anunciar o juízo de Deus sobre os ímpios e eleitos, sobre seres humanos, instituições e formas de governo. Müntzer quis unir mundo e Reino de Deus e, com isso, fugiu à realidade. Ele não conseguiu nem libertar os camponeses da servidão tampouco mostrar um caminho para a libertação. Por outro lado, também não conseguiu pregar a respeito do Reino vindouro. Anunciou juízo, mas não soube falar da graça de Deus. Os fatos ligados a ele e sua maneira de fazer teologia não foram episódicos. Em muitos sentidos, tornaram-se paradigma para o discurso teológico de várias formas de reavivamento religioso.

\section{IV}

Volto-me, agora, com mais atenção a Lutero. A temática da autoridade secular é um aspecto marginal na teologia de Lutero. No centro da teologia de Lutero estão a cristologia, a teologia da cruz, a doutrina da justificação. Por outro lado, o aspecto da autoridade secular é central, pois, ao tratarmos dele, nos encontramos frente à possibilidade de avaliarmos as potências históricas e políticas de sua teologia.

É importante não esquecer que Lutero não se voltou para discussões políticas e econômicas de seus dias por interesse próprio. Seu envolvimento se foi dando à medida que as descobertas exegéticas, feitas durante o debate em torno das indulgências, foram se tornando públicas. Camponeses, cavaleiros, burgueses, príncipes, bispos e imperador começaram a se apropriar ou a se voltar contra as descobertas exegéticas, mencionando o reformador. Desde 1521 até 1546, ano em que faleceu, Lutero foi pessoa que vivia com seus direitos políticos e eclesiásticos cassados. Esse é o contexto no qual o posicionamento de Lutero frente à autoridade secular se desenvolveu.

75 Hans-Jürgen Goertz, cit. (nota 2), p. 429. 
As observações, relativamente ao contexto em que Lutero desenvolveu sua teologia, sua ética política, social e econômica, são importantes. Elas nos evidenciam que todas as afirmações que faz são contextuais, determinadas pela situação e pelo contexto. Sua teologia política não é um sistema, mas isso não nos impede de procurar fazer dela um sistema e de questionar esse sistema quanto a sua correção e legitimidade. Há dois escritos de Lutero, nos quais ele próprio se manifestou a respeito dos limites da obediência à autoridade secular e do compromisso e direito cristão de resistir a essa mesma autoridade. Trata-se dos escritos Da Autoridade Secular, até que ponto se lhe deve obediência (1523) e o Debate Circular acerca do direito de resistência ao imperador $(1539) .^{76}$ Em outras oportunidades temos observações esparsas, das quais também nos valeremos.

Não podemos entender Lutero sem procurarmos entender o que quer dizer, quando diz "autoridade". A autoridade é, para ele, a instância que detém o monopólio do uso legítimo da violência. Essa afirmação também poderíamos fazer relativamente ao Estado moderno. No entanto, enquanto o Estado moderno é uma instituição, para Lutero a autoridade tem caráter pessoal. A autoridade mais próxima dele é o príncipe-eleitor da Saxônia. Ele não conhece o Estado democrático moderno, mesmo que saiba da existência da democracia suíça.

Ainda assim, para Lutero a autoridade de que está investido o governante não vem de baixo, mas é legitimada a partir de cima, por graça de Deus. Por graça de Deus, mas não por graça dos dirigentes eclesiásticos. Esse aspecto, aliás, é parte da grande polêmica de Lutero com a Igreja e a teologia medievais. Para ele, a autoridade secular foi diretamente investida por Deus em sua função. Sua função divina é a de manter a ordem e a de assegurar a paz interna e externa. Daí resulta que a precípua função do governante é a de zelar pelo cumprimento do direito, descrito no decálogo, que é idêntico ao direito natural. A autoridade não governa segundo o sermão do monte (Mateus 5-7), mas segundo o decálogo. Por isso, é possível que o cristão reconheça e aceite a autoridade dos governantes também entre pagãos e turcos. Não há Estado cristão. O que pode haver é um governante cristão, mesmo que este seja "ave rara".

Lutero não conhece o conceito moderno da soberania popular, mas rejeita a divinização do governante. Como para ele a autoridade do governante vem de cima e não tem sua legitimação em si mesma, sendo, pois, dependente, não há obediência cega, ilimitada em relação ao governante.

Onde está o limite à autoridade? Quando surge o direito e o compromisso de o cristão resistir à autoridade? Essas perguntas acompanham Lutero desde a publicação do Édito de Worms (1521) e o deixam temer pelas comunidades que professam a "nova fé". Para precisar com responsabilidade esses limites, direito e compromisso, Lutero valeu-se de imagens e de concepções: os dois reinos de Cristo no mundo; os regimentos da palavra e da espada, exercidos pela mão direita ou pela mão esquerda de Deus.

76 Zirkulardisputation über das Recht des Widerstandes gegen den Kaiser. Matth 19,21, 9. Mai 1539. WA 39 II, 44-51 (teses), 52-89 (debate); 90s (adendo). 
Lutero não conhece nosso conceito moderno da separação de Estado e Igreja ou de Igreja e sociedade. O mundo de Lutero é o mundo da "cristandade", do "corpo cristão". É nesse mundo da "cristandade", do "corpo cristão", que Lutero procura fazer suas afirmações acerca dos limites impostos por Deus à autoridade secular. É aqui que ele fala da obediência e da desobediência ou resistência cristãs. Caso seu pano de fundo não fosse o mundo da "cristandade", não poderíamos entender os apelos feitos à nobreza cristã de nação alemã acerca do melhoramento do estamento cristão, ${ }^{77}$ para que eliminasse os abusos existentes na Igreja, nem aos príncipes luteranos como "membros precípuos da Igreja" para que tomassem a Reforma em suas mãos. Esse contexto de "cristandade" também explica os motivos que levam o teólogo Lutero a se pronunciar frente a todos os aspectos possíveis da vida pública: escola, ensino, direito matrimonial, camponeses, usura, empréstimos, juros, guerra e paz.

Lutero não cria compartimentos estanques. Para ele, os ministros da palavra estão sujeitos à lei da autoridade, e os ministros da espada estão sujeitos à palavra de Deus. Por quê? Porque ambos são ministros de Deus. Para Lutero, não existe nenhum aspecto da vida, do mundo, da realidade, que não seja de Deus.

Ao distinguir entre dois reinos ou regimentos/regimes, Lutero nada mais quer que buscar auxílio para situações de conflito de consciência, buscando esclarecer quais as situações legítimas e ilegítimas de desobediência, respectivamente de resistência ou de desobediência. Nessa busca podem entender-se os acertos e os desacertos dos pronunciamentos de Lutero.

\section{Lutero e a autoridade após Worms (1521)}

Quando Lutero se apresentou ante Carlos V, em Worms, já estava excomungado. ${ }^{78}$ Competia à autoridade secular executar o herege impenitente. Aliás, a presença do monge agostiniano perante o imperador carece de lógica e deve-se a uma imposição dos príncipes alemães, especialmente de Frederico, o Sábio, da Saxônia, o qual não simpatizava com a doutrina de Lutero. Carlos V não tinha grandes pretensões em relação a Lutero, pois, enquanto recebia o monge, mandava queimar escritos luteranos nos Países Baixos. A única coisa que fez foi mandar Lutero retratar-se. Como esse último se negasse, mandou publicar o Édito de Worms, a 26 de maio de 1521, banindo-o. Ninguém, nem mesmo os príncipes simpatizantes, questionou a legalidade do ato do imperador. Lutero deveria ser aprisionado e executado na fogueira. Seus adeptos teriam seus bens seqüestrados e os escritos luteranos deveriam ser incinerados. Estabelecia-se a censura à produção teológica.

Segundo o Édito, Lutero era visto como revolucionário: "Ele elimina toda a obediência e governo e nada escreve além do que serve e aproveita à revolução, separação, guerra, morte, latrocínio e incêndio e ao abandono total da fé cristã. Pois assim como ensina uma vida livre e autônoma, excluída de toda a lei e total-

Cf. Lutero, M. Pelo Evangelho de Cristo. Obras selecionadas de momentos decisivos da Reforma. Porto Alegre e São Leopoldo: Concórdia e Sinodal, 1984, p. 75-142.

${ }_{78}$ Cf. meu ensaio Lutero e a Dieta de Worms de 1521. In: DREHER, M. N. (ed.). Reflexões em torno de Lutero v. II. São Leopoldo: Sinodal, 1984, p. 79-91. 
mente animalesca, ele próprio é ser humano livre e autônomo, que condena e oprime todas as leis". ${ }^{79}$ As palavras do Édito de Worms exageram. Lutero não conclama à guerra, nem à morte ou ao latrocínio. Não é incendiário e quer, justamente, o retorno à fé cristã. Também não prega a eliminação de leis ou de governo. Por outro lado, foi revolucionário, ao redefinir o relacionamento de autoridade espiritual e temporal. Seu movimento teve como conseqüência o desmoronamento da hierarquia e a perda das propriedades eclesiásticas. Basta que se lembre a secularização dos bens dos mosteiros. A autoridade secular teve que assumir o sistema escolar e os cuidados pelos mendicantes, questões que até então haviam sido da alçada da Igreja. Com o auxílio da imprensa, a Reforma provocou uma mobilização sem precedentes da opinião pública, levando as questões teológicas até para dentro de movimentos que tinham bem outras origens, como o movimento dos camponeses.

Interessante é a reação de Lutero ao Édito. Para ele, o Édito era uma lei imperial que ficou sendo ameaça para toda a sua vida. Somente em 1555, na Paz de Augsburgo, a questão seria alterada. Questões políticas não permitiram a aplicação do Édito em todo o Império. O imperador vivia fora do Reino Alemão, envolvido em guerras. Frederico o Sábio manteve Lutero sob prisão domiciliar no Wartburgo. Em alguns territórios, como a Baviera, os Países Baixos e a Áustria, a perseguição aos luteranos foi violenta. Ameaçado, confinado ao território da Saxônia, vendo correligionários sendo mortos ou perseguidos, Lutero viu-se forçado a se posicionar. Em março de 1522, desobedecendo ao Eleitor da Saxônia, abandonou o Wartburgo. Responderia a Frederico o Sábio que não necessitava de proteção: "Essa questão não pode receber conselho ou ser auxiliada por nenhuma espada; Deus somente é que deve aqui laborar, sem qualquer tipo de cuidado e auxílio humano. Por isso, quem mais crê, é quem mais há de poder aqui auxiliar". Caso Lutero for aprisionado, o Eleitor não terá culpa, pois deve obediência ao imperador. Aliás, "não pode opor-se à autoridade, que me quer prender ou matar; pois ninguém pode desobedecer ou opor-se à autoridade, a não ser aquele que a instituiu, caso contrário será revolta e contra Deus" ${ }^{80}$ Lutero proíbe o Eleitor de usar violência contra a autoridade imperial e está disposto a sofrer, seguindo a Jesus.

Da mesma maneira, proíbe as classes populares de se rebelarem contra a decisão imperial em uma fiel admoestação a todos os cristãos, para que se precavenham ante revolução e revolta: "Os que lêem e compreendem corretamente minha doutrina não fazem revolta. Não o aprenderam de mim". O que se deve fazer é resistir, fazendo uma "revolta espiritual".

A questão vai ser, então, amplamente discutida, em 1523, no escrito Da autoridade secular, até que ponto se lhe deva obediência. Em 1520, Lutero escrevera À nobreza cristã de nação alemã..., dizendo, o que deveriam fazer; agora escreve o que devem deixar de fazer. "Pois Deus, o onipotente, enlouqueceu os nossos prín-

79 Cf. RADE, Martin. Doktor Martin Luthers Leben, Thaten und Meinungen, auf Grund reichlicher Mitteilungen aus seinen Briefen und Schriften dem Volke erzählt. V. 2. Neusalza i. S.: Hermann Oeser, 1887, p. 193.

${ }^{80}$ WA Br 2, 455s.

81 1522, WA 8, 673s 
cipes, de sorte que pensam poderem fazer e ordenar a seus súditos o que quiserem; e também os súditos se enganam, quando crêem estarem obrigados a cumprir tudo isso plenamente". ${ }^{82}$ A autoridade secular não pode intrometer-se nas questões de Deus, querendo determinar o que deve ser crido. Ela também não tem autoridade para julgar e condenar hereges. Em setembro de 1522, havia sido editada a tradução do Novo Testamento feita por Lutero. Em muitos lugares, o texto foi confiscado. "Em Meissen, Baviera, Brandenburgo e outros lugares, os tiranos publicaram um édito, segundo o qual se deveriam entregar os Novos Testamentos nas repartições (públicas). Nesse caso, seus súditos devem agir da seguinte maneira: não devem entregar uma folhinha sequer, nenhuma letra sequer, sob pena de perderem a salvação eterna. Pois quem o fizer entrega Cristo nas mãos de Herodes, porque os príncipes procedem como os assassinos de Cristo, como Herodes (Mateus 2. 13, 16). Por outro lado, os súditos devem tolerá-lo, quando for dada a ordem de revistar-lhes as casas e levar, pela força, livros ou bens. Não se deve resistir ao mal, mas tolerá-lo; não se deve, porém, aprová-lo, nem colaborar com ele ou seguir e obedecer-lhe, nem com um passo ou dedo sequer". ${ }^{83}$

Lutero vai ainda além. Não só não se deve mover um pé ou dedo sequer, mas deve-se, nesse caso, resistir com palavras e confessar a desobediência: quem permitir que a autoridade lhe tire a fé ou livros, nega a Deus. Mais: nega a Deus quem cumprir qualquer ordem, na qual a autoridade exige que se cometa injustiça. Em todo o escrito, Lutero conclama seus leitores a resistirem com a palavra, não só os teólogos, mas todos. A virtude básica da política é a coragem civil de dizer o que deve ser dito.

Em 1526, Lutero vai repensar toda a problemática da resistência e da desobediência à autoridade, no escrito Se soldados também podem se encontrar em estado de beatitude. ${ }^{84}$ Para ele, quem começa uma guerra não tem razão. Tal guerra é ofensiva e, por isso, injusta. Aqui o cristão é obrigado a desobedecer à autoridade.

2. Lutero e a autoridade após a Dieta de Espira (1529). Sabemos que Carlos V se ausentou da Alemanha de 1521 a 1530. Nesse período, a Reforma teve grande expansão. Muitos territórios, seus príncipes e súditos tornaram-se luteranos. Na Dieta de Espira, de 1529, fez-se a tentativa de reverter a situação. Houve o protesto dos príncipes luteranos, donde se originou o nome "protestantes". Em 1530, a situação piorou bastante, quando Carlos V, no auge de seu poder, retornou à Alemanha para presidir a Dieta de Augsburgo. Pretendia ele reunificar os adeptos da velha e da nova fé, mas a publicação da Confissão de Augsburgo e a da Confutatio evidenciaram que, entrementes, isso se tornara impossível.

O avanço dos turcos e a crônica falta de dinheiro dos habsburgos não permitiram que as decisões da Dieta de Worms fossem postas em prática. Carlos V que, logo após a Dieta de Augsburgo, teve que voltar a abandonar a Alemanha, necessitava de soldados e de dinheiro alemães. Mas, os príncipes luteranos começaram a se preparar para uma eventual guerra contra o imperador. A Liga de Esmalcalda

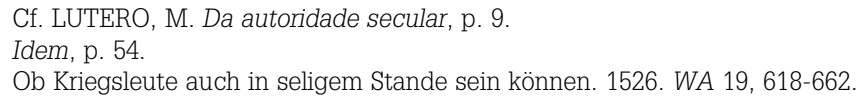


solicitou de Lutero que dissesse se uma defesa armada frente ao imperador era lícita. Lutero descartou qualquer ataque preventivo, não queria sequer que houvesse preparativos para uma eventual defesa. Por fim, foi convencido por juristas que lhe afirmaram que o imperador não tinha autoridade para impor, por meio de violência, uma decisão de Dieta referente a questões religiosas.

Lutero passa a considerar que a lealdade frente ao direito e à lei está acima da lealdade à autoridade: "Os direitos estão acima de um senhor ou de um tirano, sem mais; pois os mesmos são imutáveis, sempre certos e constantes; um ser humano, no entanto, é inconstante e instável, na maioria das vezes e preferencialmente segue os seus instintos, caso não for impedido; é por isso que estamos mais comprometidos e compromissados com os direitos e as leis do que com um tirano". ${ }^{85}$ Aqui é desenvolvido aspecto novo que não estava contido no escrito $D a$ autoridade secular, de 1523.

Na década de 1530, a concepção de Lutero relativamente ao direito e ao dever de resistir à autoridade vai continuar a ser desenvolvida. Lutero sempre se posicionou favoravelmente ao direito de legítima defesa frente a ladrões e assassinos. Em 1539, em uma Conversa à Mesa, vai afirmar que esse direito de legítima defesa também diz respeito à autoridade e que, em último caso, também é possível que se organize a resistência coletiva à autoridade. Vejamos o texto da Conversa à Mesa:

Caso pois, um patife, independentemente da pessoa, quisesse violentar minha mulher e filha e eu estivesse vendo, aí eu, deveras, iria deixar o cristão de lado e iria usar o cidadão (Weltperson), estrangulá-lo-ia em sua ação ou gritaria por socorro. Pois, quando a autoridade está ausente e a gente não pode valer-se dela, aí existe o direito popular o qual permite que a gente peça socorro aos vizinhos. ${ }^{86}$

Em uma outra Conversa à Mesa, da década de 30, Lutero chega a justificar o assassinato do tirano como ato de legítima defesa coletiva. Diz que, caso um tirano violentar sucessivamente mulheres e filhas e se apropriar indebitamente dos bens destes, aí os súditos podem reunir-se e eliminá-10 ${ }^{87}$. Lutero não está justificando revolução, nem o assassinato político, mas está bastante próximo da justificação da revolução.

Em fins de janeiro de 1539, Lutero, Melanchthon e Butzer apresentaram um memorando ao príncipe-eleitor, elaborado por Melanchthon. Nele se lê:

Assim como o Evangelho confirma a autoridade, assim também confirma os direitos naturais e legais; e não há dúvida de que cada pai deve, segundo as suas possibilidades, proteger esposa e criança frente ao assassinato público; e aqui não há distinção entre um assassino privado e o imperador, quando faz uso fora de seu ministério de autoridade injusta e, especialmente, quando faz uso de autoridade injusta pública ou notória, pois violência pública põe fim a todos os compromissos entre súdito e senhor,

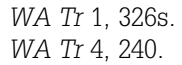


segundo o direito natural; semelhante é esse caso, quando o senhor quer induzir o súdito à blasfêmia ou à idolatria. ${ }^{88}$

3. Lutero e a autoridade após a convocação do Concílio por Paulo III, em 1536.

Em 1536, Paulo III convocou um Concílio que deveria ter a finalidade de eliminar a heresia luterana. Em 1538, encerrava-se a guerra de Carlos V com a França e o partido católico se reunia em Nürnberg. Aos protestantes parecia que a guerra religiosa iria eclodir.

Esse é o pano de fundo que leva Lutero a formular setenta teses para um debate previsto para o mês de abril de 1539, em Wittenberg. As teses abordam questões como autoridade, obediência e resistência. Quando, em 1546, começou a Guerra de Esmalcalda, os protestantes mandariam reimprimir as teses de 1539. Lutero morrera em fevereiro desse ano. ${ }^{89}$

As teses são radicais. Base para elas são a distinção dos dois regimentos ou as duas tábuas do decálogo, a primeira falando dos deveres em relação a Deus, a segunda falando dos deveres em relação aos seres humanos. Logo no início, Lutero coloca sua velha tese de que o cristão deve estar pronto para o sofrimento. Não pode erguer sua mão contra a autoridade, quando esta o persegue por causa de Cristo. Quando, porém, for atacado por causa da primeira tábua por uma outra pessoa que não a autoridade, deve resistir como cidadão deste mundo, usando de violência, "pois deves estar certo de que ele não te quer matar por causa de Cristo, mas por causa de teus bens". Lutero justifica a guerra de defesa contra os católicos. E defesa faz parte dos deveres de um cristão.

Mas como é que fica a questão frente à guerra que se avizinha e que vai ser comandada pelo imperador em pessoa? Será que aqui não vale o mandamento do sofrimento? A resposta de Lutero nos deixa estupefatos. Na guerra religiosa que se avizinha, o imperador não está agindo como imperador, mas como executor das aspirações papais. E o papa não é autoridade, nem espiritual nem temporal. O papa é um tirano, ele é o anomos, a daemone arreptus, aquele que é radicalmente desobediente e fora da lei (Efésios 2,2), possuído pelo demônio. Esse tirano anomos derruba as tábuas da lei e, fazendo isso, derruba as bases de toda a ordem humana. Ele declara sua própria arbitrariedade norma para a ação humana, fazendo-a substituir a distinção de bem e mal, dada no direito natural. Esse tirano é o Berwolf. Nós o denominaríamos de lobisomem. Quando invade o redil das ovelhas, toda a aldeia se reúne para eliminá-lo, a ele e a seus auxiliares (teses 63-68). Sua eliminação é necessária. Se acontecer que alguém queira impedir a execução desse tirano, isto é, se imperador ou reis não o quiserem permitir, aí é necessário um levante popular.

Qual a causa dessa radicalidade de Lutero? Já vimos que, em 1537, o papa convocara um Concílio geral. Finalidade do Concílio era a eliminação dos luteranos. Não era esse o Concílio que os protestantes desejavam. Lutero rejeita, pois,

WA Br 8,3293 - Anexo.

Cf. WA 39 II, 39-91. 
veementemente tal Concílio. Ele sabe, além disso, que o papa convocara o concílio pressionado pelo próprio imperador Carlos V. O imperador não é apenas ajudante do papa. Carlos V entendia-se como defensor da cristandade. Dentro dessa concepção, mandara redigir o Édtito de Worms. O próprio Carlos V é, pois, o tirano a daemone arreptus, o diabolos que confunde os dois regimentos.

Qual a causa dessa radicalidade de Lutero? A radicalidade de Lutero é conseqüência de uma situação que foi se radicalizando sempre mais e que, em 1539, punha em risco toda a situação dos protestantes. A Reforma está ameaçada de extinção. Lutero não põe de lado sua disposição pessoal de sofrer. Com o que não pode concordar é com a eliminação das Igrejas reformatórias. Aqui há responsabilidade histórica.

4. Como vê Lutero a autoridade? Formulo algumas teses:

4.1. A autoridade é instituída por Deus em seu ministério. Por isso, os cristãos lhe devem obediência.

4.2. Como é Deus quem dá a autoridade ao governante, devemos obediência incondicional a Deus, mas não ao governante. Nem mesmo o militar cristão deve obediência absoluta ao governante.

4.3. O limite da obediência está dado pela palavra de Deus: o Evangelho e o decálogo.

4.4. O cristão não obedece cegamente. Ele tem que formar sua opinião própria.

4.5. Quando a autoridade o quer forçar a fazer injustiça, tem o compromisso de desobedecer, de resistir com a palavra, de sofrer com a palavra.

4.6. Ao lado desses elementos básicos, devemos constatar que Lutero respondeu a questão da resistência de diversas maneiras, ao longo de sua vida:

a) Lutero reconhece um direito privado de legítima defesa.

b) Lutero fala, a partir de 1530, de um direito coletivo de legítima defesa.

c) Em 1539, esse direito se transforma em compromisso.

4.7. Lutero nega a possibilidade de revolução por questões políticas ou sociais. Vê-a, no entanto, como compromisso, quando a autoridade assume o lugar de Deus.

Estudados Müntzer e Lutero, impõe-se uma conclusão. Começo com Lutero. Lutero vê Deus agindo de duas maneiras, para conter o pecado do ser humano. 1. Ele atinge o coração do ser humano, por meio da palavra pregada, que se lhe apresenta como Lei e Evangelho. 2. Utiliza a autoridade como seu instrumento. Ela leva o ser humano à obediência externa, através da justiça civil. No mundo caído, a autoridade tem uma função necessária. Seus esforços e a correspondente obediência dos súditos levam à paz e à justiça. Isso não é alcançado pela pregação da palavra, e, se for tentado, os lobos apascentarão os cordeiros. Por outro lado, a autoridade secular não consegue obter para os súditos a bem-aventurança eterna. Se ela o tentar, só produzirá hipócritas. Igreja e Estado dependem um do 
outro. A novidade em Lutero é que essa dependência é descrita de tal maneira que o Evangelho não pode transformar-se em lei e que o cumprimento da lei civil não é visto como pressuposto para a salvação eterna, nem pode ser tido por desnecessário, como acontece com Müntzer. A justiça nestas duas esferas, Igreja e Estado, é distinta, mas Deus é o senhor de ambas, e o ser humano necessita de ambas. Por causa do ser humano, Deus se vale da Igreja e do Estado. Como a autoridade é servidora de Deus, de modo algum se pode formular a tese de que ela esteja sujeita à Igreja.

Lutero não formulou uma Filosofia do Estado. Nem sequer pensou em dar ao Estado autonomia. Buscou interpretar o mundo de seu tempo e mostrar aos cristãos, seus contemporâneos, as tarefas que Deus lhes dava. Especialmente contra Müntzer e adeptos quis demonstrar que cristãos podem servir seu próximo em amor, colocando-se à disposição da ordem política. Pode parecer que a autoridade esteja fundamentalmente a serviço da ira de Deus, pois usa a espada para manter a ordem interna e a defesa externa. No uso da espada, porém, está o amor de Deus: a paz deve ser preservada. Lutero não viu motivos para sugerir mudanças nas estruturas do Estado. A situação de crise em que vivia permitiu-lhe formular os direitos de resistência do cidadão. Sua maior contribuição talvez esteja na fundamentação teológica da "mundanalidade do mundo". Aqui contribuiu para as reflexões futuras.

Müntzer percebeu um mundo carente de mudanças radiciais. Viu o regime de cristandade como responsável pelos males do mundo. Foi anticlerical e anarquista. Propôs a teocracia. Sua proposta não construi Estado. Ambos fizeram parte das profundas mudanças que estavam acontecendo no século XVI. 